\title{
Exploring the Antecedents of Job Crafting: A Conditional Process Analysis
}

\author{
Domenico Berdicchia $^{1} \&$ Giovanni Masino ${ }^{1}$ \\ ${ }^{1}$ University of Ferrara, Italy \\ Correspondence: Giovanni Masino, University of Ferrara, Italy. E-mail: giovanni.masino@unife.it
}

Received: June 14, 2017

Accepted: October 3, 2017

Online Published: November 20, 2017

doi:10.5539/ijbm.v12n12p1

URL: https://doi.org/10.5539/ijbm.v12n12p1

\begin{abstract}
In this paper we investigate whether the relationship between leader and members (Leader-Member Exchange, LMX), a key element of work organization, constitutes a relevant antecedent for job crafting. We also investigate whether role breadth self-efficacy mediates such relationship. Then, we look at organizational-level policies, and explore whether human resource initiatives aimed at exposing employees to developmental experiences may influence both the direct relation between LMX and job crafting and the above mentioned mediated relation. Results of a conditional process analysis (a mediated moderation model) with a sample of 172 store level workers indicate that LMX has a positive influence on job crafting. Results also show that developmental experiences moderates the positive direct relationship of LMX on most job crafting behaviors. Moreover, we also found that developmental experiences moderate the positive indirect effect of LMX on some job crafting behaviors via role breadth self-efficacy. These direct and indirect effects of LMX are stronger when developmental experiences are lower. Managerial implications and directions for future research are discussed.
\end{abstract}

Keywords: Job crafting, Proactivity, LMX, Self-Efficacy, Developmental experiences

\section{Introduction}

Literature on job crafting has been described as "an exciting area of research" (Oldham \& Hackman, 2010: 470) because of the profound implications that proactivity in the workplace and, more generally, a genuine bottom-up approach to job design may have for individuals and organizations. A significant number of studies show the relevance of proactivity and job crafting in relation to work engagement and performance (Bakker, Tims, \& Derks, 2012), creativity and human flourishing (Demerouti, Bakker, \& Gevers, 2015), self-efficacy (Van den Heuvel, Demerouti, \& Peeters, 2015), work satisfaction and well-being (Tims, Bakker, \& Derks, 2013). Thus, it seems necessary to improve our understanding about individual and contextual elements that may influence job crafting behaviors (Berg, Dutton, \& Wrzesniewski, 2013).

Our study contributes to such literature by exploring whether Leader-Member Exchange (LMX) directly and / or indirectly influences job crafting behaviors through an increase in workers' role breadth self-efficacy. We also explore the idea that developmental experiences may influence both the direct relation between LMX and job crafting and the relation mediated by role breadth self-efficacy.

In available literature, the relationship between supervisory and job crafting behaviors is considered both crucial and controversial. On the one hand, prominent scholars argue that working "out of the limelight" of management's gaze may multiply the perceived opportunities for Job Crafting (Wrzesniewski \& Dutton, 2001). Subsequent contributions, however, argue that supervisors and leaders may have a positive influence on job crafting by allowing more autonomy, shared information and increased dialogue (Tims \& Bakker, 2010) (Berg, Grant, \& Johnson, 2010), developing competences, skills and self-efficacy (Leana, Appelbaum, \& Shevchuk, 2009; Tims, Bakker, \& Derks, 2014). Thus, it seems important to test empirically these arguments. By studying the relationship between LMX and job crafting, and role breadth self-efficacy as a mediator, we believe we may shed some light on the above mentioned debate.

Moreover, we included in our model developmental experiences as a moderator of the direct and indirect effects, since Human Resource Management literature and Social Influence theory imply a complex interplay between the role of leaders and the role of organizational initiatives and policies in orienting discretionary behavior (Purcell \& Hutchinson, 2007). On the one hand, it is argued that supervisors may have a significant role for a 
successful implementation of HR practices. Thus, a symbiotic relationship may develop in which both supervisors and organizational practices strengthen each other's ability to influence employees' outcome (Kuvaas \& Dysvik, 2010). On the other hand, it is also argued that supportive organizational initiatives (such as providing developmental experiences for the employees) may compensate or even substitute the role of leaders, thereby decreasing the relevance of the latter (Bass, 1985; Podsakoff \& MacKenzie, 1994).

The goal of our study is to help clarifying why and how LMX positively influences job crafting behaviors, hence contributing to this literature and also providing useful indications for organizations interested in promoting proactivity and, more specifically, job crafting in the workplace.

\section{Theoretical Background and Hypotheses}

\subsection{The Job Demands-Resources Job Crafting Model}

Job crafting (JC) is a form of proactive behavior through which workers redesign their job (Wrzesniewski \& Dutton, 2001). A common approach to the empirical study of job crafting is the Job Demands-Resources model (Tims \& Bakker, 2010), according to which workers craft their jobs by changing their job resources and demands.

Job resources are physical, psychological, social or organizational job elements that allow pursuing work goals and promoting personal growth. Insufficient resources generate anxiety, stress, lower motivation, disengagement, withdrawal (Bakker \& Demerouti, 2007) and prevent employees from goal attainment and personal development (Bakker et al., 2003). On the contrary, sufficient resources decrease depersonalization, emotional exhaustion (Fernet et al., 2013), while increasing satisfaction and motivation (Tims et al., 2013b), work engagement (Hakanen et al., 2008), and the ability to develop further resources (Xanthopoulou et al., 2012).

Job demands, on the other hand, are work features that require sustained physical, cognitive or emotional effort. A distinction between challenging job demands and hindering job demands has been proposed (Lepine et al., 2005). Hindering job demands prevent employees from achieving goals by generating stress and anxiety. Challenging job demands, even when experienced as complex and difficult, provide increased mastery experiences, satisfaction, work engagement excitement, passion and personal development (Bakker \& Demerouti, 2007).

According to the Job Demands-Resources job crafting model, we can observe job crafting in terms of one (or more) of four types of proactive behaviors, specifically aimed at: i) increasing structural resources; ii) increasing social resources; iii) increasing new challenging job demands; iv) decreasing hindering job demands.

\subsection{The Relationship between LMX and Job Crafting}

According to Social Exchange Theory (Liden, Sparrowe, \& Wayne, 1997) high LMX describes a relation between leader and member characterized by mutual trust and frequent exchanges that go beyond the content of the formal job description. The leader provides the follower with social and emotional support, more autonomy, responsibilities, information and feedback, participation to decision making, while the follower reciprocates with increased effort (Graen \& Scandura, 1987). Such reciprocity may trigger initiatives that are not expected or formally prescribed by the organization (Liden \& Graen, 1980). It may also lead to increased willingness to accept tasks that are not formally prescribed (Liden et al., 1997). Thus, reciprocity may induce members to seek new challenging job demands that go beyond the formal perimeter of their role.

LMX may discourage job crafting in terms of decreasing hindering job demands. First, this may result from a reciprocity obligation towards the leader, as reducing job demands, however hindering, may be seen by the supervisor as a disappointment. Second, reciprocity may also induce leaders to help employees to face their most difficult demands, thereby reducing workers' need to avoid them (Schriesheim, Neider, Scandura, \& Tepper, 1992). Finally, appreciation and emotional support may motivate followers to increase their effort when facing hindering demands (Scott and Bruce, 1994).

At the same time, workers with high LMX may be compelled to craft their job by seeking more resources. First, their awareness of resource availability and accessibility may increase, as resources are made more clearly available by the leader (Liden et al., 1997). Also, mutual trust may convince workers to acquire more feedback and other kinds of support from their leaders. Ashford, Blatt, and Vande Walle (2003) showed that a supervisor can influence individuals' feedback seeking through reducing fears of potential image costs. In addition, recognition of an increased job influence, decision latitude and autonomy should make it easier for workers to change their job demands and resources (Leana et al., 2009; Petrou, Demerouti, Peeters, Schaufeli, \& Hetland, 2012; Tims et al., 2013). Finally, high LMX allows workers to improve their learning and mental abilities, and seek proactively new forms of social support (Grant \& Ashford, 2008), to access more information, different 
points of view, new technical skills and competencies (Panari, Guglielmi, Simbula, \& Depolo, 2010), to think critically about their wok activities (Scholl, 2001) and, consequently, to identify more opportunities to craft their job (Tims \& Bakker, 2010).

\subsection{The Mediating Effect of Role Breadth Self-Efficacy}

Role breadth self-efficacy describes the subjects' perception about their ability to perform a set of tasks that go beyond those strictly required by their formal role (Axtell \& Parker, 2003; Parker, 1998; Parker, Williams, \& Turner, 2006). Thus, it is similar to self-efficacy (Bandura (1977), but it encapsulates better than generic self-efficacy the idea of proactivity at work (Bindl \& Parker, 2010; Parker, 2000; Parker \& Collins, 2010; Strauss, Griffin, \& Rafferty, 2009).

Here we hypothesize a positive relation between LMX and role breadth self-efficacy for a number of reasons. Available research shows that LMX may increase the perception of different forms of efficacy (Schyns, 2004; Walumbwa et al., 2011). First, LMX may increase role breadth self-efficacy by improving enactive mastery in relation to an enlarged and proactive role (Parker, 1998). Indeed, delegation (Liden et al., 1997) is one of the key elements of LMX (Scandura et al., 1986). Second, LMX may influence role breadth self-efficacy through vicarious experiences and social persuasion. When exchanges and mutual trust between leader and member increase, it is more likely that the leader will become a role model for workers (Walumbwa et al., 2011). Also, opportunities for verbal persuasion and encouragement to tackle and overcome work challenges are more likely to increase (Schyns, 2004). Such exchanges are likely to improve the worker's role breadth self-efficacy not just through the social support that becomes available, but also through an improved awareness of the goals to be achieved and the expectations to be met (Axtell \& Parker, 2003; Parker, 1998).

The hypothesized positive effect of role breadth self-efficacy on job crafting is also based on several ideas that are found in available literature. First, workers with higher role breadth self-efficacy will comprehend or build more resourceful work environments (Kohn \& Schooler, 1982) and believe they can utilize new resources effectively (Van Wingerden et al., 2015). At the same time, workers with higher role breadth self-efficacy are more likely to seek new challenging job demands because their belief to be able to perform effectively may protect them from the fear of sanctions associated with negative performances in extra-role tasks (Morrison \& Phelps, 1999). Individuals with high self-efficacy are more likely to be proactive in order to satisfy their ambitions and to fully utilize their abilities (Wood \& Bandura, 1989), even by engaging in more complex activities or more challenging goals. Finally, role breadth self-efficacy may also have an influence on job crafting behaviors such as decreasing hindering job demands thanks to increased persistence and effort spent in the face of obstacles. Social cognitive theory shows that people who doubt their own ability tend to decrease their effort, settle for mediocre solutions or abandon the activity, while those with a strong belief in their capabilities tend to increase their effort (Bandura, Adams, \& Beyer, 1977).

\subsection{The Moderating Effect of Developmental Experiences}

Wayne, Shore, and Liden (1997) define developmental experiences as the discretionary initiatives through which organizations support and improve the personal and professional development of the employees, typically (but not exclusively) through various forms of formal and informal training. Developmental experiences may satisfy the need of personal growth by increasing the sense of self-determination, control, impact, meaning and enjoyment at work (Rego, Pina, \& Cunha, 2009). Developmental experiences may also trigger a sense of competency, autonomy and effectiveness, stimulate creativity, entrepreneurship and prevent a sense of stagnation and frustration (Kets de Vries, 2001).

Building on these premises, we believe that developmental experiences may create psychological conditions that are very relevant for job crafting. Workers tend to reciprocate the attention received from the organization by increasing their effort and dedication (Eisenberger, Huntington, Hutchison, \& Sowa, 1986), because of a personification process (Levinson, 1965) which leads them to attribute traits and qualities to organizations and reciprocate initiatives that are beneficial for them (Wayne et al., 1997).

Thus, the obligation to reciprocate generated by a higher level of developmental experiences may explain why employees increase their proactive behaviors aimed at increasing their challenging job demands. For the same reason, they may be more likely to avoid decreasing their hindering job demands. At the same time, the climate of trust and openness perceived by employees in organizations making significant investments in their development may facilitate initiatives aimed at acquiring new structural and social job resources.

Also, similarly to what happens when high LMX is present, developmental experiences may help employees to have a clearer understanding of job requirements and, more generally, of the work environment as a whole. 
Specifically, their understanding of what social and structural resources are necessary for their work activities is also improved, thereby increasing their propensity to acquire new resources (Tims \& Bakker, 2010). Similarly, workers' awareness of how to craft the perimeter of their job by increasing challenging job demands is also improved (Wrzesniewski \& Dutton, 2001). Such improved understanding may decrease the uncertainty and ambiguity related to hindering job demands, thereby reducing the need to avoid them.

We also argue that developmental experiences may moderate the relation between LMX and role breadth self-efficacy by influencing, just like LMX, the most important determinants of self-efficacy. Through developmental experiences workers are typically trained to face more challenging activities such as new projects and tasks and to strengthen their skills (Wayne et al., 1997). This will improve their sense of mastery and, by consequence, their self-efficacy, thanks to both the newly acquired capabilities (Gist \& Mitchell, 1992) and the opportunity to utilize and test such skills in new, difficult tasks that are proposed during such development programs (Conger \& Kanungo, 1998). Just like when LMX is high, developmental experiences provide opportunities for workers to observe behavioral models needed for good performance and learn from them (Conger \& Kanungo, 1998; Gist, 1989; Gist \& Mitchell, 1992), and that may increase self-efficacy through role modeling and verbal persuasion. According to Gist and Mitchell (1992: 204) "persuasion should take the form of counseling or coaching to clarify the pros and cons of various performance strategies". Initiatives such as on-the-job training and work simulations may help workers to become more aware of the task attributes and the behavioral, analytical or psychological performance and effort needed to achieve good work results in new tasks and situations, thereby improving role breadth self-efficacy (Axtell \& Parker, 2003).

\subsection{A Moderated-Mediation Framework}

In this study we hypothesize that the positive relation between LMX and Job Crating behaviors aimed at increasing structural job resources, social job resources and challenging job demands are mediated by role breadth self-efficacy. We also hypothesize that the negative relation between LMX and JC behaviors aimed at decreasing hindering job demands is mediated by role breadth self-efficacy as well.

Furthermore, we hypothesize that developmental experiences moderate the direct effect of LMX and the first stage of indirect effects, via role breadth self-efficacy, on Job Crating behaviors. We can summarize our moderated-mediation model in the following way (figure 1).

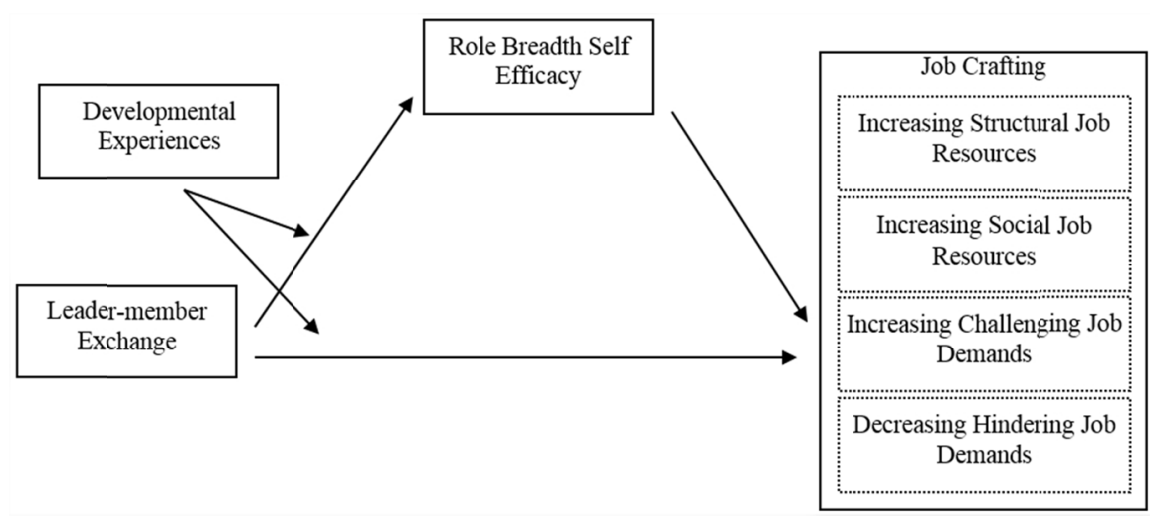

Figure 1. Schematic representation of the model

Hypothesis 1: developmental experiences moderate the positive direct relationship between LMX and (H1a) increasing structural job resources, (H1b) increasing social job resources, (H1c) increasing challenging job demands and (H1d) the negative direct relationship between LMX and decreasing hindering job demands such that the effects are stronger when developmental experiences are lower.

Hypothesis 2: developmental experiences moderate the positive indirect effect of LMX and (H2a) increasing structural job resources, (H2b) increasing social job resources, (H2c) increasing challenging job demands and $(\mathrm{H} 2 \mathrm{~d})$ the negative indirect relationship between LMX and decreasing hindering job demands via role breadth self-efficacy such that the effects are stronger when developmental experiences are lower. 


\section{Methodology}

\subsection{Participants and Procedures}

Our study was conducted in a major Italian retail company with the voluntary participation of store-level workers. Although these workers operate in different store aisles and departments, their tasks are identical, e.g., merchandising, re-stocking and customer assistance. Indeed, the company considers their formal organizational position as being the same. Additionally, they receive the same training and have the same work contracts. After agreeing with the Human Resources Director about the methodology, the goals and the content of the study, we delivered 250 questionnaires together with a cover letter in which we summarized the goals of the study and reassured the potential participants about the anonymity of their responses. We provided a box in which respondents were asked to put their filled questionnaire. After about 3 weeks we collected 172 questionnaires correctly filled (69\% response rate). The average age of respondents was 40.7 years old $(\mathrm{SD}=11.66)$, the minimum 19 and maximum 66; 55\% percent were male. The average job tenure was 10.26 years $(\mathrm{SD}=9.30)$. About $14 \%$ of respondents have a bachelor degree or more, $70.9 \%$ a high school diploma, $15.1 \%$ a middle school diploma or less.

\subsection{Measures}

The measuring scales were translated in the local language (Italian). We utilized a professional translator. To validate the translation, we used the back translation method (Brislin et al., 1973).

Leader member exchange (LMX). In order to measure LMX we utilized Scandura and Graen's (1984) LMX-7 scale. The scale was anchored on a 7-point format ranging from 1 (=strongly disagree) to 7 (= strongly agree). A sample item is the following: "I have an effective working relationship with my supervisor". Cronbach's alpha for this study was 0.98 .

Role-breadth self-efficacy. Role breadth self-efficacy was measured through the 10-item scale proposed by Parker (1998). Employees were asked how confident they would feel about carrying out a set of tasks beyond their formal job, for example analyzing a long-term problem to find a solution. The response scale ranged from 1 (= not at all confident) to 5 (= very confident). Cronbach's alpha for this study was 0.95 .

Developmental experiences. We measured developmental experiences through the 4-item developed by Wayne et al. (1997). A sample item is the following: "In the positions that I have held in this company, I have often been assigned projects that have enabled me to develop and strengthen new skills". The range of responses varied from 1 (=strongly disagree) to 7 (= strongly agree). Cronbach's alpha for this study was 0.92 .

Job Crafting. We measured increasing structural job resources and increasing social job resources, increasing challenging job demands and decreasing hindering job demands through the sub-dimensions of the job crafting scale developed by Tims et al. (2012). Increasing structural job resources, increasing social job resources, increasing challenging job demands include 5 items each, while decreasing hindering job demands utilizes 6 items. Sample items for each variable are the following: "I try to develop my capabilities" for increasing structural job resources; "I ask colleagues for advice" for increasing social job resources; "When an interesting project comes along, I offer myself proactively as project co-worker" for increasing challenging job demands; "I make sure that my work is mentally less intense" for decreasing hindering job demands. The range of responses varied from 1 (= never) to 5 (= very often). Cronbach's alpha estimates for these scales were, respectively, 0.84 , $0.91,0.94,0.92$.

Control variables. We controlled for several potentially relevant variables. First, we controlled for job tenure (number of years in the same job) because, according to Berg et al. (2010b), job experience may influence job crafting behaviors in a variety of ways. On the one hand, long tenured employees may be less inclined to craft their job because they are more accustomed to their tasks. On the other hand, longer-tenured members may have a better understanding of available opportunities for job crafting thanks to a deeper knowledge of their job or the organizational context.

We also controlled for age and gender since both may influence employees' preferences for certain work characteristics (Bipp, 2010) and, by consequence, their motivation for job crafting.

Moreover, we controlled for education, as seen in in other studies (Tims et al., 2012), because higher education may facilitate job crafting initiatives in several ways. First, because education may provide more knowledge and other resources, but also because highly educated employees usually occupy higher level roles, characterized by more autonomy and responsibility, which may allow for more job crafting opportunities (Bakker et al., 2012). For the same reasons we also controlled for formal position. We distinguished between three formal levels: a low level, which includes workers with production duties; an intermediate level, including direct supervisors with 
administrative duties, and a managerial level. According to Berg et al. (2010a), at different ranks, employees may enjoy different degrees of autonomy or freedom to act as job crafters.

\subsection{Analysis}

We studied the structural validity of the scales through a confirmatory factor analysis in AMOS. The hypothesized seven factor model (LMX, role breadth self-efficacy, developmental experiences, increasing structural job resources, increasing social job resources, increasing challenging job demands and decreasing hindering job demands $)$ exhibits an acceptable fit $(\chi 2[798]=1349.47, \chi 2 / \mathrm{df}=1.69, \mathrm{CFI}=0.92, \mathrm{IFI}=0.92$, TLI $=0.91$, RMSEA $=0.06$ ). We compared the hypothesized model with several other models, but none produced a better fit than the hypothesized model. A six-factor model factor model where role breadth self-efficacy and developmental experiences were combined in one factor $(\chi 2[804]=1806.24, \chi 2 / \mathrm{df}=2.25, \mathrm{CFI}=0.85, \mathrm{IFI}=0.85$, TLI $=0.84$, RMSEA $\left.=0.09, \Delta \chi^{2}=456.76, \Delta \mathrm{df}=6, \mathrm{p}<0.1\right)$; a six-factor model where LMX and developmental experiences were combined in one factor $(\chi 2[804]=1860.54, \chi 2 / \mathrm{df}=2.31, \mathrm{CFI}=0.84, \mathrm{IFI}=0.84$, TLI $=0.83$, $\mathrm{RMSEA}=0.09, \Delta \chi 2=511.06, \Delta \mathrm{df}=6, \mathrm{p}<0.1)$; a six-factor model where increasing structural job resources and increasing social job resources were combined in one factor $(\chi 2[804]=1688.04, \chi 2 / \mathrm{df}=2.1, \mathrm{CFI}=0.86$, IFI $=$ $0.86, \mathrm{TLI}=0.85, \mathrm{RMSEA}=0.08, \Delta \chi 2=338.52, \Delta \mathrm{df}=6, \mathrm{p}<0.1)$; a six-factor model where increasing challenging job demands and decreasing hindering job demands were combined in one factor $(\chi 2[804]=1999.84$, $\left.\chi 2 / \mathrm{df}=2.48, \mathrm{CFI}=0.82, \mathrm{IFI}=0.82, \mathrm{TLI}=0.81, \mathrm{RMSEA}=0.09, \Delta \chi^{2}=650.36 \Delta \mathrm{df}=6, \mathrm{p}<0.1\right)$; a five-factor model where increasing challenging job demands and decreasing hindering job demands were combined in one factor and increasing structural job resources and increasing social job resources were combined in another factor $\left(\chi 2[809]=2419.29, \chi 2 / \mathrm{df}=2.99, \mathrm{CFI}=0.76, \mathrm{IFI}=0.76, \mathrm{TLI}=0.74, \mathrm{RMSEA}=0.11, \Delta \chi^{2}=1069.81, \Delta \mathrm{df}\right.$ $=11, \mathrm{p}<0.1)$ and a four-factor model where all job crafting behaviors (increasing structural job resources, increasing social job resources, increasing challenging job demands and decreasing hindering job demands ) were combined in one factor $(\chi 2[813]=2786.13, \chi 2 / \mathrm{df}=3.42, \mathrm{CFI}=0.70, \mathrm{IFI}=0.70, \mathrm{TLI}=0.68$, RMSEA $=$ $0.12, \Delta \chi 2=1436.65, \Delta \mathrm{df}=15, \mathrm{p}<0.1)$. We also tested the single factor model with all the items loaded on a common factor, which showed a very poor fit $(\chi 2[819]=5183.79, \chi 2 / \mathrm{df}=6.33, \mathrm{CFI}=0.34, \mathrm{IFI}=0.34, \mathrm{TLI}=$ 0.31 , RMSEA $=0.18$ ). These results confirm that the utilized scales did possess adequate discriminant validity.

\section{Results}

We tested the hypothesized direct effect and first-stage moderated-mediation model using the SPSS version of the PROCESS macro (Hayes, 2013), which generates bias-corrected 95\% confidence intervals for making statistical inference.

More specifically, we used the Hayes (2012) SPSS PROCESS macro Model 8. We tested four models 8 with LMX as the independent variable (X), developmental experiences as the moderator (W) and role breadth self-efficacy as the mediator (M) and (respectively) increasing structural job resources, increasing social job resources, increasing challenging job demands and decreasing hindering job demands as outcome (Y). We used age, gender, tenure and education as covariates that simultaneously predicts both the mediator and outcome.

A point estimate was considered significant when it did not include 0 between the upper (ULCI) and the lower (LLCI) bound of the $95 \%$ bootstrap confidence intervals. Bootstrap confidence intervals were constructed using 5000 resamples. One of the advantages of the bootstrapping procedure is that the bootstrap confidence intervals respect in a better way the irregularity of the sampling distribution, hence allowing more accurate inferences.

Table 1 shows the descriptive statistics and correlations among variables.

Table 1. Means, standard deviations, and correlations among all study variables

\begin{tabular}{|c|c|c|c|c|c|c|c|c|c|c|c|c|c|c|}
\hline & Variables & Mean & SD & 1 & 2 & 3 & 4 & 5 & 6 & 7 & 8 & 9 & 10 & 11 \\
\hline 1. & Age & 40.73 & 11.66 & - & & & & & & & & & & \\
\hline 2. & Gender & 0.55 & 0.50 & -0.11 & - & & & & & & & & & \\
\hline 3. & $\begin{array}{l}\text { Job } \\
\text { Tenure }\end{array}$ & 10.26 & 9.30 & $0.60 * * *$ & 0.14 & - & & & & & & & & \\
\hline 4. & Education & 1.99 & 0.54 & 0.09 & 0.07 & -0.13 & - & & & & & & & \\
\hline 5. & LMX & 4.19 & 1.33 & $-0.33^{* * *}$ & 0.12 & $-0.26^{* *}$ & $-0.24 * *$ & $(0.98)$ & & & & & & \\
\hline 6. & RBSE & 3.34 & 0.83 & -0.04 & 0.12 & 0.09 & $-0.30 * * *$ & $0.30 * * *$ & $(0.95)$ & & & & & \\
\hline
\end{tabular}




\begin{tabular}{llllllllllllll}
\hline 7. & DEV & 3.93 & 1.05 & 0.01 & $0.16^{*}$ & -0.12 & $-0,12$ & $0.25^{* *}$ & $0.36^{* * *}$ & $(0.92)$ & & & \\
8. ISTJR & 4.16 & 0.53 & $-0.19^{*}$ & 0.08 & -0.02 & $-0.20^{* *}$ & $0.35^{* * *}$ & $0.41^{* * *}$ & $0.27^{* * *}$ & $(0.84)$ & & \\
9. ISOJR & 2.77 & 0.80 & $-0.32 * * *$ & 0.09 & $-0.39^{* * *}$ & -0.01 & $0.28^{* * *}$ & 0.07 & $0.18^{*}$ & 0.11 & $(0.91)$ & \\
10. ICJD & 3.32 & 0.97 & -0.13 & 0.10 & -0.13 & -0.14 & $0.36^{* * *}$ & $0.39^{* * *}$ & $0.35^{* * *}$ & $0.31^{* * *}$ & $0.31^{* * *}$ & $(0.94)$ \\
11. DHJD & 2.48 & 0.80 & 0.02 & 0.04 & 0.08 & -0.11 & -0.07 & -0.10 & $-0.19^{*}$ & -0.08 & $-0.21^{* *}$ & $-0.19 * *$ & $(0.92)$
\end{tabular}

Note. $\mathrm{n}=172$. Reliability estimates (Cronbach's alpha) are listed in parentheses on the diagonal. Gender: male $=1$ and female $=0$. Education: 1 = middle school diploma or less; 2 = high school diploma; 3 = bachelor degree or more. LMX: Leader-member exchange; RBSE: Role Breadth Self-Efficacy; DEV: Developmental Experiences; RBSE: Role Breadth Self-Efficacy; ISTJR: Increasing Structural Job Resources; ISOJR: Increasing Social Job Resources; ICJD: Increasing Challenging Job Demands; DHJD: Decreasing Hindering Job Demands.

$p<.05$

$* * p<.01$

$* * * p<.001$

The regression results of PROCESS are shown in Table 2.

Table 2. Regression results of process

\begin{tabular}{lllllllllll}
\hline & RBSE & \multicolumn{3}{c}{ ISTJR } & \multicolumn{3}{c}{ ISOJR } & \multicolumn{2}{l}{ ICJD } & \multicolumn{2}{c}{ DHJD } \\
\hline Predictors & Coeff. & SE & Coeff. & SE & Coeff. & SE & Coeff. & SE & Coeff. & SE \\
\hline Intercept & $3.93^{* * *}$ & 0.30 & $4.05^{* * *}$ & 0.27 & $3.47^{* * *}$ & 0.42 & $2.72^{* * *}$ & 0.50 & $3.19^{* * *}$ & 0.47 \\
Age & -0.01 & 0.01 & $-0.01^{* *}$ & 0.01 & -0.01 & 0.01 & -0.01 & 0.01 & -0.01 & 0.04 \\
Gender & 0.12 & 0.11 & -0.01 & 0.07 & $-0.33^{* *}$ & 0.12 & -0.04 & 0.13 & 0.16 & 0.12 \\
Job Tenure & $0.02^{* *}$ & 0.01 & $0.01^{*}$ & 0.01 & $-0.02^{*}$ & 0.01 & 0.01 & 0.01 & 0.01 & 0.01 \\
Education & $-0.26^{*}$ & 0.11 & -0.01 & 0.07 & 0.08 & 0.11 & $0.29^{* *}$ & 0.10 & $-0.24^{*}$ & 0.12 \\
LMX & $0.12^{* *}$ & 0.05 & $0.08^{* *}$ & 0.03 & $0.10^{*}$ & 0.05 & $0.16^{* *}$ & 0.07 & -0.02 & 0.05 \\
DEV & $0.28^{* * *}$ & 0.06 & $0.11^{* *}$ & 0.04 & $0.14^{*}$ & 0.06 & $0.26^{* * *}$ & 0.05 & -0.12 & 0.07 \\
LMX x DEV & $-0.11^{* *}$ & 0.04 & $-0.08^{* *}$ & 0.02 & $-0.08^{*}$ & 0.04 & $-0.14^{* *}$ & 0.05 & -0.02 & 0.04 \\
RBSE & & & $0.14^{* *}$ & 0.05 & -0.01 & 0.08 & $0.24^{* *}$ & 0.07 & -0.10 & 0.08 \\
R & & & 0.30 & & 0.26 & & 0.30 & & 0.07 &
\end{tabular}

Note. $\mathrm{n}=172$. Table values are path estimates from the estimated model. Entries are unstandardized coefficient estimates. LMX: Leader-member exchange; RBSE: Role Breadth Self-Efficacy; DEV: Developmental Experiences; RBSE: Role Breadth Self-Efficacy; ISTJR: Increasing Structural Job Resources; ISOJR: Increasing Social Job Resources; ICJD: Increasing Challenging Job Demands; DHJD: Decreasing Hindering Job Demands. $* \mathrm{p}<.05$

$* * \mathrm{p}<.01$

$* * * \mathrm{p}<.001$

LMX was positively related to role breadth self-efficacy, increasing structural job resources, increasing social job resources, increasing challenging job demands, $(b=0.12,0.08,0.10,0.16, p<0.01,0.01,0.05,0.01$ respectively), but not to decreasing hindering job demands $(b=-0.02$, ns). Role breadth self-efficacy was positively related to increasing structural job resources $(b=0.14, p<0.01)$ and increasing challenging job demands $(b=0.24, p<0.01)$, but not to increasing social job resources and decreasing hindering job demands $(b$ $=-0.01,-0.1$ respectively, both not significant). Developmental experiences were positively related to role breadth self-efficacy, increasing structural job resources, increasing social job resources and increasing challenging job demands $(b=0.28,0.11,0.14,0.26, p<0.001,0.01,0.05,0.001$ respectively), but not to decreasing hindering job demands $(b=-0.12$, ns). Last, the interaction between LMX and developmental experiences were related to role breadth self-efficacy, increasing structural job resources, increasing social job resources, increasing challenging job demands $(b=-0.11,-0.08,-0.08,-0.14, p<0.01,0.01,0.05,0.01$ respectively), but not to decreasing hindering job demands $(b=0.02$, ns).

Direct and indirect effects of LMX on job crafting at high and low levels of developmental experiences are shown in table 3. 
Table 3. Direct and indirect effects of LMX on Increasing Structural Job Resources, Increasing Social Job Resources, Increasing Challenging Job Demands and Decreasing Hindering Job Demands at high and low levels of Developmental Experiences

\begin{tabular}{|c|c|c|c|c|c|c|c|c|c|c|c|c|}
\hline \multirow[b]{3}{*}{ Outcome } & \multirow[b]{3}{*}{ Mediators } & \multicolumn{5}{|c|}{ Conditional direct effects } & & & \multicolumn{4}{|c|}{ Conditional indirect effects } \\
\hline & & \multirow[b]{2}{*}{ Path } & \multirow[b]{2}{*}{ Effect } & \multirow[b]{2}{*}{ SE } & \multirow[b]{2}{*}{$\mathrm{t}$} & \multirow[b]{2}{*}{$\mathrm{p}$} & \multicolumn{2}{|c|}{$95 \% \mathrm{CI}$} & \multirow[b]{2}{*}{ Effect } & \multirow[b]{2}{*}{ Boot SE } & \multicolumn{2}{|c|}{ Boot $95 \% \mathrm{CI}$} \\
\hline & & & & & & & LL & UL & & & LL & UL \\
\hline \multirow[t]{4}{*}{ ISTJR } & Direct Effect & Low & 0.16 & 0.04 & 4.04 & 0.00 & 0.08 & 0.24 & & & & \\
\hline & & High & 0.01 & 0.04 & 0.09 & 0.92 & -0.72 & 0.08 & & & & \\
\hline & RBSE & Low & & & & & & & 0.03 & 0.02 & 0.01 & 0.10 \\
\hline & & High & & & & & & & 0.01 & 0.01 & -0.01 & 0.02 \\
\hline \multirow[t]{4}{*}{ ISOJR } & Direct Effect & Low & 0.18 & 0.06 & 2.90 & 0.00 & 0.09 & 0.31 & & & & \\
\hline & & High & 0.02 & 0.06 & 0.29 & 0.77 & -0.10 & 0.14 & & & & \\
\hline & RBSE & Low & & & & & & & -0.01 & 0.02 & -0.04 & 0.04 \\
\hline & & High & & & & & & & 0.01 & 0.01 & -0.01 & 0.01 \\
\hline \multirow[t]{4}{*}{ ICJD } & Direct Effect & Low & 0.31 & 0.07 & 4.19 & 0.00 & 0.16 & 0.46 & & & & \\
\hline & & High & 0.01 & 0.07 & 0.21 & 0.83 & -0.13 & 0.16 & & & & \\
\hline & RBSE & Low & & & & & & & 0.06 & 0.03 & 0.01 & 0.12 \\
\hline & & High & & & & & & & 0.01 & 0.01 & -0.02 & 0.04 \\
\hline \multirow[t]{4}{*}{ DHJD } & Direct Effect & Low & -0.01 & 0.07 & -0.01 & 0.99 & -0.14 & 0.14 & & & & \\
\hline & & High & -0.04 & 0.07 & -0.58 & 0.56 & -0.17 & 0.09 & & & & \\
\hline & RBSE & Low & & & & & & & -0.02 & 0.02 & -0.10 & 0.01 \\
\hline & & High & & & & & & & -0.01 & 0.01 & -0.02 & 0.01 \\
\hline
\end{tabular}

Note. $\mathrm{n}=172$. Entries are unstandardized coefficient estimates $(95 \%$ confidence interval). CI, confidence interval; LL, lower limit; UL, upper limit. RBSE: Role Breadth Self-Efficacy; ISTJR: Increasing Structural Job Resources; ISOJR: Increasing Social Job Resources; ICJD: Increasing Challenging Job Demands; DHJD: Decreasing Hindering Job Demands.

When employees have a lower level of developmental experiences, LMX has a direct $(b=0.16, p<0.001)$ and indirect effect on increasing structural job resources via role breadth self-efficacy $(b=0.03,95 \%$ bias-corrected CI $[0.01,0.10])$.

When employees have a higher level of developmental experiences, LMX did not have a direct $(b=0.01, \mathrm{~ns})$ or indirect effects on increasing structural job resources via role breadth self-efficacy $(b=0.01,95 \%$ bias-corrected CI [-0.01, 0.02]).

Thus, $\mathrm{H} 1 \mathrm{a}$ and $\mathrm{H} 2 \mathrm{a}$ are supported.

When employees have a lower developmental experiences, LMX has a direct effect on increasing social job resources $(b=0.18, p<0.001)$ but does not have an indirect effect on increasing social job resources via role breadth self-efficacy $(b=-0.01,95 \%$ bias-corrected CI $[-0.04,0.04])$.

When employees have a higher developmental experiences, LMX does not have a direct $(b=0.02$, ns) or indirect effect on increasing social job resources via role breadth self-efficacy $(b=0.01,95 \%$ bias-corrected CI [- 0.01 , $0.01])$.

Thus, H1b is supported, while H2b is not supported.

When employees have lower developmental experiences, LMX has a direct $(b=0.31, p<0.001)$ and indirect effect on increasing challenging job demands via role breadth self-efficacy $(b=0.06,95 \%$ bias-corrected CI $[0.01,0.12])$.

When employees have higher developmental experiences, LMX does not have a direct $(b=0.01$, ns $)$ or indirect effect on increasing challenging job demands via role breadth self-efficacy $(b=0.01,95 \%$ bias-corrected $C I$ $[-0.02,0.04])$.

Thus, H1c and H2c are supported. 
When employees have lower developmental experiences, LMX does not have a direct $(\mathrm{b}=-0.01$, ns) or indirect effect on decreasing hindering job demands via role breadth self-efficacy $(b=-0.02,95 \%$ bias-corrected $\mathrm{CI}$ $[-0.10,0.01])$.

When employees have higher developmental experiences, LMX does not have a direct $(b=-0.04$, ns) or indirect effect on increasing challenging job demands via role breadth self-efficacy $(b=-0.01,95 \%$ bias-corrected $\mathrm{CI}$ $[-0.02,0.01])$.

Thus, H1d and H2d are not supported.

We used the Johnson-Neyman technique to plot the moderating effect of developmental experiences on the relationship between LMX and Job crafting, as shown in Figure 2. LMX has stronger direct effect on increasing structural job resources (figure 2a), increasing social job resources (figure $2 \mathrm{~b}$ ) and increasing challenging job demands (figure 2c) when developmental experiences are lower. In addition, as we can see from Figure 2, the direct effect of LMX on increasing structural job resources, increasing social job resources and increasing challenging job demands is significant for any value of developmental experiences respectively lower than 4.23, 4.02 and 4.29.

Similarly, we used the Johnson-Neyman technique to plot the conditional indirect effects. The conditional indirect effects of LMX on increasing structural job resources (figure 2d) and on increasing challenging job demands (figure 2e) via role breadth self-efficacy are stronger when developmental experiences are lower and these indirect effects are significantly far from 0 for any value of developmental experiences respectively lower than 4.30 (for Figure 2d) and 4.31 (for Figure 2e).
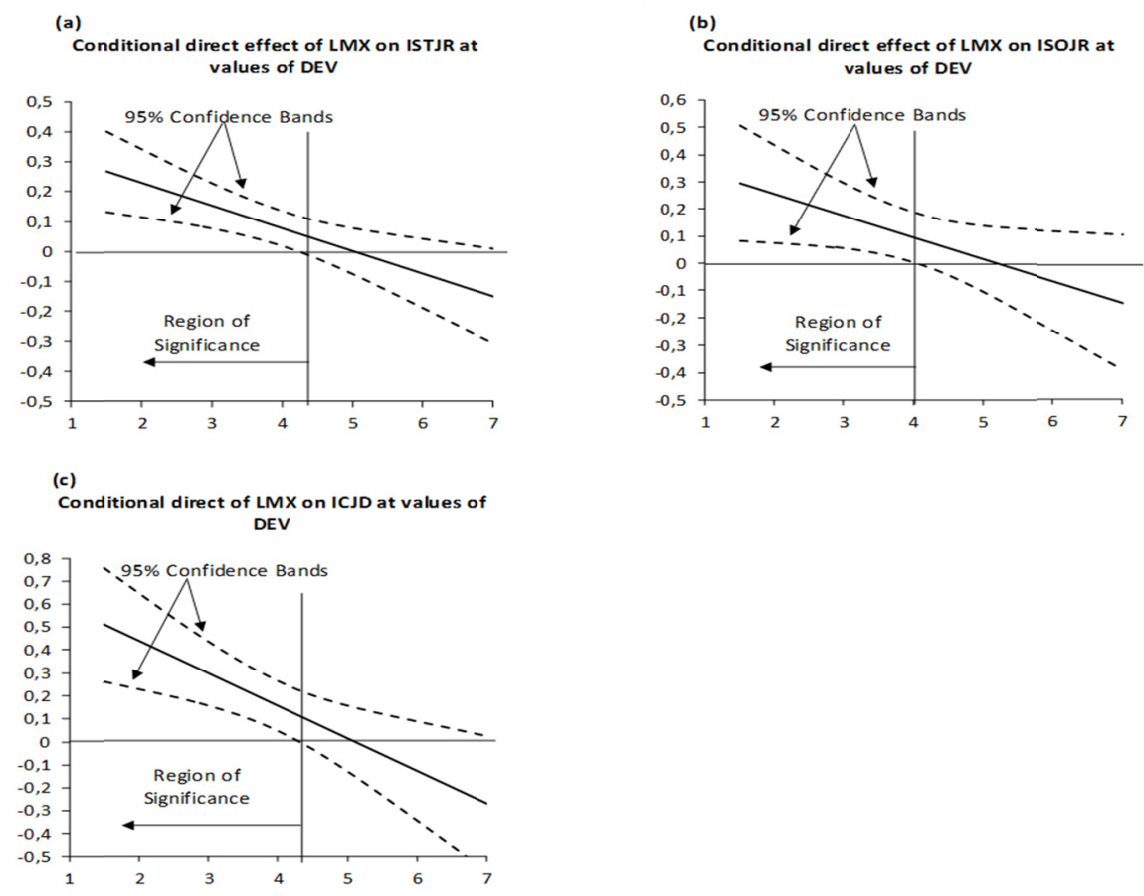

(d)
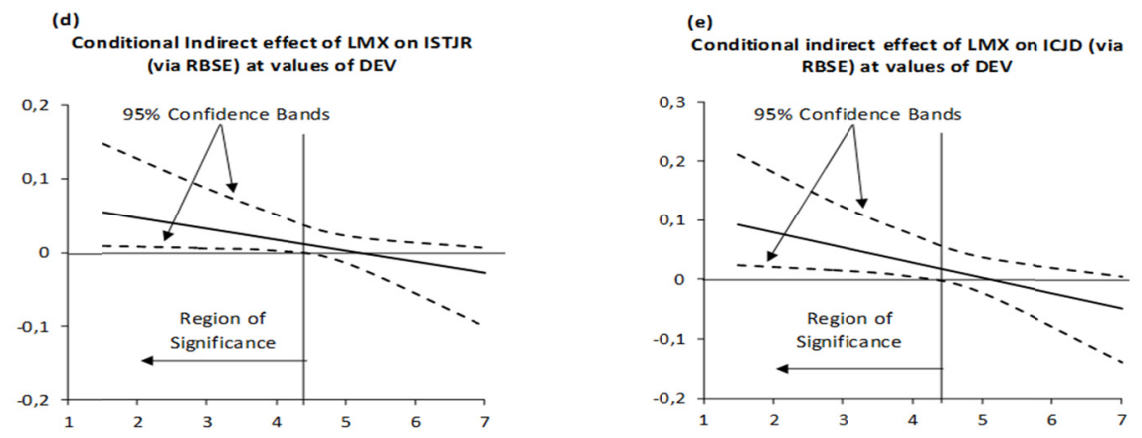

Figure 2. Conditional direct and indirect effects of LMX on Job Crafting at values of Developmental Experiences 


\section{Discussion}

\subsection{Theoretical Implications}

Our results show, first of all, that LMX plays an important role in promoting job crating. While a low LMX may actually generate conformity and discourage job crating, a high quality LMX, based on mutual exchange, trust and support, may actually have an opposite, positive effect. This result is consistent to what was found by Leana et al. (2009) about the positive role that a supportive supervision plays in encouraging job crating. This is also generally consistent with evidence found by Hornung, Rousseau, Glaser, Angerer, and Weigl (2010) about how LMX may facilitate a process of negotiated re-definition of job characteristics (i. e. task i-deal). While we agree that LMX may lead to a more flexible or expandable zones of acceptance that workers and their role senders develop in relation to job activities and performance, our results show that such processes do not necessarily derive from negotiated agreements. In more general terms, our study seems to suggest that high LMX may enable processes of bottom-up job redesign that are quite different from the traditional top-down approach (Oldham \& Hackman, 2010).

Second, our results show that, contrary to what we expected, a high LMX does not decrease job crafting behaviors aimed at decreasing hindering demands. This might be explained by two opposing phenomena. On the one hand, high LMX provides resources and motivation that allow workers to better tackle hindering demands. On the other hand, a relationship based on trust and support may decrease the psychological risk associated with behaviors aimed at decreasing job demands (Morrison \& Phelps, 1999; Parker, Bindl, \& Strauss, 2010; Vardaman, Gondo, \& Allen, 2012). If both phenomena are true, the overall effect of LMX might be non significant.

A third result concerns the role of role breadth self-efficacy. We found that psycological processes related to the relationship between employees and supervisors are significant in explaining job crafting behaviors. High LMX may indeed provide the employees with the material and psycological resources that will improve their sense of self-efficacy, with positive consequences on their propensity to craft their job. Interestingly, though, we did not find that role breadth self-efficacy mediates the relationship between LMX and job crafting behaviors aimed at increasing social resources. This may be explained if we consider that social resources concern advice, help and feedback from the supervisor and / or colleagues (Tims \& Bakker, 2010). Literature on feedback seeking (Ashford et al., 2003) and help seeking (Lee, 1997) show that these types of behaviors imply a social cost. For this reason, employees may want to limit the amount of social resources they seek even when they are easily available, as such behavior may signal incompetence and generate dependence (Lee, 1997). Thus, employees with high role breadth self-efficacy may feel compelled to count more on their own abilities and less on seeking social resources, in order to avoid such social costs. As a consequence, this phenomenon might compensate our original argument about the positive effect of role breadth self-efficacy on job crafting, resulting in a non-significant total effect.

We also explored the moderating effect of developmental experiences on the direct and indirect relationship between LMX and job crafting. Similarly to what was found in previous studies, supportive supervision and HR practices are both crucial in encouraging employees' discretional behavior (Kuvaas \& Dysvik, 2010; Purcell \& Hutchinson, 2007). However, our results show that high LMX and high developmental experiences generate similar effects on employees' role breadth self-efficacy and as antecedents of job crafting, hence they tend to act as substitutes. Such effect appears to be consistent to what other empirical studies found (Maertz, Griffeth, Campbell, \& Allen, 2007) and to classic substitute for leadership theory (Kerr \& Jermier, 1978). We verified the substitute effect further by following the recommendation by Dionne, Yammarino, Howell, and Villa (2005). We found for role breadth self-efficacy and for each job crafting behavior positively associated to LMX the existence of 5 conditions: (i) a leadership main effect model, (ii) a substitute main effect model, (iii) a joint effects model, (iv) a mediation model, where the substitute mediates the relation between leadership and outcome, and (v) the moderation effect. This result outlines a twofold contribution that our paper provides to both leadership and job crafting literatures. First, our findings enrich the reflection on the relationship between leadership and job crafting. Second, our findings provide further support for the traditional, but still debated substitutes for leadership theory.

\subsection{Practical Implications}

It seems increasingly important to understand how to promote job crafting in organizations facing complex environments and markets. Our study shows some of the tools and initiatives that organizations may effectively use to do it. First, supervisors' ability to establish a high quality relationship with their followers seems crucial to facilitate job crafting. Thus, organizations should develop leadership skills and, more specifically, they should 
encourage their leaders and supervisors to utilize dialogue, information exchanges, reciprocity, openness, support, role modeling, delegation of responsibilities and autonomy. Systematic literature reviews show that training supervisors in these behaviors is an effective way to increase LMX quality (Dulebohn, Bommer, Liden, Brouer, \& Ferris, 2011). Examples of such initiatives are work-related interactions aimed at encouraging seniors to coach, guide, and mentor subordinates (Bhal, Gulati, \& Ansari, 2009), programs that help supervisors to learn skills associated with supportive work behaviors, as well as meetings and other opportunities to increase exchanges (Restubog, Bordia, \& Bordia, 2009).

According to Walumbwa, Cropanzano, \& Goldman (2011: 764) "no firm can guarantee high-quality LMX 100\% of the time". Thus, organizations interested in facilitating job crafting should also implement additional initiatives that may complement high LMX, such as providing developmental experiences to their employees. Indeed, our findings suggest that organizations should provide developmental experiences especially to those employees that are not in a position to benefit from the resources and support provided by supervisors. At the same time, when the organizations provide developmental experiences to its employees, supervisors may use their time to take better care of their relationship with those workers who have less opportunities to improve their skills and abilities through such developmental initiatives.

\section{Limitations and Future Research Directions}

The main limitation of our study concerns its cross-sectional nature. Thus, we cannot be certain of the causal direction of the tested relations. We built our model based on available theories and evidence, but alternative interpretations may be proposed. Future research could adopt a longitudinal approach to verify the causality of relations.

Second, data on the all variables in our study were based on self-reports, and this may imply the possibility of common-method variance. However, common-method variance has been suggested to be less of an issue in moderated regression (Pierce, Gardner, Dunham, \& Cummings, 1993). Also, the guarantee of anonymity to respondents has probably alleviated the common-method bias. Regardless, extending the study over time and establishing a time lag between measures of independent and dependent variables might further decrease the common-method variance bias. Also, utilizing measures coming from multiple sources would have been desirable.

Third, in this study we utilized data gathered within a single organization from workers in the same formal position. Thus, we suggest caution in generalizing our results and, at the same time, we hope that other scholars will replicate our study in other organizations.

Fourth, we focused on role breadth self-efficacy as a mediating variable between LMX and job crafting. However, there may be many other relevant mediating variables. Leadership is still significantly under-explored in job crafting literature. Autonomy, empowerment, participation to decision making, job satisfaction, trust, are just a few examples, among many, of variables that may play a relevant role in mediating LMX and job crafting.

Similar considerations should be relevant about contextual variables. In our study we focused on developmental experiences, but several other human resource management practices and policies may substitute or neutralize the effect of leadership on job crafting. For example, job design practices such as job enrichment might have a similar effect. Similarly, psychological and personal variables might also play a relevant role. For example, work and motivational orientations might be important in supporting job crafting behaviors (Berg et al., 2010) by intrinsically motivating workers. These are just a few examples of a vast number of interesting research hypotheses that could be tested in future studies.

\section{References}

Ashford, S. J., Blatt, R., \& VandeWalle, D. (2003). Reflections on the Looking Glass: A Review of Research on Feedback-Seeking Behavior in Organizations. Journal of Management, 29(6), 773-799. http://dx.doi.org.10.1016/S0149-2063_03_00079-5

Axtell, C. M., \& Parker, S. K. (2003). Promoting role breadth self-efficacy through involvement, work redesign and training. Human Relations, 56(1), 113-131. http://dx.doi.org.10.1177/0018726703056001452

Bakker, A. B., Tims, M., \& Derks, D. (2012). Proactive personality and job performance: The role of job crafting and work engagement. Human Relations, 65(10), 1359-1378. http://dx.doi.org.10.1177/0018726712453471

Bandura, A. (1977). Self-efficacy: The exercise of control. New York: Freeman.

Bandura, A., Adams, N. E., \& Beyer, J. (1977). Cognitive Processes Mediating Behavioral Change. Journal of Personality and Social Psychology, 35(3), 125-139. http://dx.doi.org.10.1037/0022-3514.35.3.125 
Bass, B. (1985). Leadership and performance beyond expectations. New York: The Free Press.

Berg, J. M., Dutton, J. B., \& Wrzesniewski, A. (2013). Job crafting and meaningful work. In B. J. Dik \& Z. Byrne, S. \& M. F. Steger (Eds.), Purpose and Meaning in the Workplace: (pp. 81-104). Washington, Dc: American Psychological Association.

Berg, J. M., Grant, A. M., \& Johnson, V. (2010). When Callings Are Calling: Crafting Work and Leisure in Pursuit of Unanswered Occupational Callings. Organization Science, 21(5), 973-994. http://dx.doi.org.10.1287/orsc.1090.0497

Bhal, K. T., Gulati, N., \& Ansari, M. A. (2009). Leader-member exchange and subordinate outcomes: test of a mediation model. Leadership \& Organization Development Journal, 30(2), 106-125. http://dx.doi.org.10.1108/01437730910935729

Bindl, U. K., \& Parker, S. K. (2010). Proactive work behavior: forward-thinking and change-oriented action in organizations. In S. Zedeck (Ed.), APA handbook of industrial and organizational psychology (Vol. 2, pp. 567-598). Washington, DC: American Psychological Association.

Conger, J. A., \& Kanungo, R. N. (1998). The Empowerment Process: Integrating Theory and Practice. Academy of Management Review, 13(3), 471-482. http://dx.doi.org.10.2307/258093

Demerouti, E., Bakker, A. B., \& Gevers, J. M. P. (2015). Job crafting and extra-role behavior: The role of work engagement and flourishing. Journal of Vocational Behavior, 91, 87-96. http://dx.doi.org/10.1016/j.jvb.2015.09.001

Dionne, S. D., Yammarino, F. J., Howell, J. P., \& Villa, J. (2005). Substitutes for leadership, or not. The Leadership Quarterly, 16(1), 169-193. http://dx.doi.org.10.1016/j.leaqua.2004.09.012

Dulebohn, J. H., Bommer, W. H., Liden, R. C., Brouer, R. L., \& Ferris, G. R. (2011). A Meta-Analysis of Antecedents and Consequences of Leader-Member Exchange: Integrating the Past with an Eye toward the Future. Journal of Management, 38 1715-1759. http://dx.doi.org.10.1177/0149206311415280

Eisenberger, R., Huntington, R., Hutchison, S., \& Sowa, D. (1986). Perceived organizational support. Journal of Applied Psychology, 71, 500-507. http://dx.doi.org.10.1037/0021-9010.71.3.500

Gist, M. E. (1989). The Influence Of Training Method On Self-Efficacy And Idea Generation Among Managers. Personnel Psychology, 42(4), 787-805. http://dx.doi.org.10.1111/j.1744-6570.1989.tb00675.x

Gist, M. E., \& Mitchell, T. R. (1992). Self-efficacy: a theoretical analysis of its determinants and malleabillty. Academy of Management Review 17(2), 183-211. http://dx.doi.org.10.2307/258770

Graen, G. B., \& Scandura, T. A. (1987). Toward a psychology of dyadic organizing. In B. Staw \& L. L. Cumming (Eds.), Research in Organizational Behavior (Vol. 9, pp. 175-208). Greenwich, CT: JAI Press.

Grant, A. M., \& Ashford, S. J. (2008). The dynamics of proactivity at work. Research in Organizational Behavior, 28, 3-34. http://dx.doi.org.10.1016/j.riob.2008.04.002

Hayes, A. F. (2013). Introduction to mediation, moderation, and conditional process analysis: A regression based approach. New York: The Guilford Press.

Hornung, S., Rousseau, D. M., Glaser, J., Angerer, P., \& Weigl, M. (2010). Beyond top-down and bottom-up work redesign: Customizing job content through idiosyncratic deals. Journal of Organizational Behavior, 31(2), 187-215. http://dx.doi.org.10.1002/job.625

Kerr, S., \& Jermier, J. M. (1978). Substitutes for leadership: Their meaning and measurement. Organizational Behavior and Human Performance, 22, 375-403. http://dx.doi.org.10.1016/0030-5073(78)90023-5

Kets de Vries, M. F. R. (2001). Creating authentizotic organizations: Well-functioning individuals in vibrant companies. Human Relations, 54(1), 101-111. http://dx.doi.org.10.1177/0018726701541013

Kuvaas, B. \& Dysvik, A. (2010). Exploring alternative relationships between perceived investment in employee development, perceived supervisor support and employee outcomes. Human Resource Management Journal, 20(2) 138-156. http://dx.doi.org.10.1111/j.1748-8583.2009.00120.x

Leana, C., Appelbaum, E., \& Shevchuk, I. (2009). Work process and quality of care in early childhood education: the role of job crafting. Academy of Management Journal, 52(6), 1148-1168. http://dx.doi.org.10.5465/AMJ

Lee, F. (1997). When the Going Gets Tough, Do the Tough Ask for Help? Help Seeking and Power Motivation in Organizations. Organizational Behavior And Human Decision Processes, 72(3), 336-363. http://dx.doi.org.10.3758/s13423-014-0794-z 
Levinson, H. (1965). Reciprocation: The relationship between man and organization. Administrative Science Quarterly, 9, 370-390. http://dx.doi.org.10.2307/2391032

Liden, R. C., \& Graen, G. B. (1980). Generalizability of the vertical dyad linkage model of leadership. Academy of Management JournaI, 23(3), 451-465. http://dx.doi.org.10.2307/255511

Liden, R. C., Sparrowe, R. T., \& Wayne, S. J. (1997). Leader-member exchange theory: The past and potential for the future. Research in Personnel and Human Resources Management, 15, 47-119.

Maertz, C. P., Griffeth, R. W., Campbell, N. S., \& Allen, D. G. (2007). The Effects of Perceived Organizational Support and Perceived Supervisor Support on Employee Turnover. Journal of Organizational Behavior, 28(8) 1059-1075. http://dx.doi.org.10.1108/00483481211189947

Morrison, E. W., \& Phelps, C. C. (1999). Taking Charge At Work: Extrarole Efforts To Initiate Workplace Change. Academy of Management Journal, 42(4), 403-419. http://dx.doi.org.10.2307/257011

Oldham, G. R., \& Hackman, J. R. (2010). Not what it was and not what it will be: The future of job design research. Journal of Organizational Behavior, 32(2-3), 463-479. http://dx.doi.org.10.1002/job.678

Panari, C., Guglielmi, D., Simbula, S., \& Depolo, M. (2010). Can an opportunity to learn at work reduce stress?: A revisitation of the job demand-control model. Journal of Workplace Learning, 22(3), 166-179. http://dx.doi.org.10.1108/13665621011028611

Parker, S. K. (1998). Enhancing Role Breadth Self-Efficacy: The Roles of Job Enrichment and Other Organizational Interventions. Journal of Applied Psychology, 83(6), 835-852. http://dx.doi.org.10.1037//0021-9010.83.6.835

Parker, S. K. (2000). From Passive to Proactive Motivation: The Importance of Flexible Role Orientations and Role Breadth Self-efficacy. Applied Psychology: An International Review, 49(3), 447-469. http://dx.doi.org.10.1111/1464-0597.00025

Parker, S. K., \& Collins, C. G. (2010). Taking stock: Integrating and differentiating multiple proactive behaviors. Journal of Management, 36(3), 633-662. http://dx.doi.org.10.1177/0149206308321554

Parker, S. K., Bindl, U. K., \& Strauss, K. (2010). Making Things Happen: A Model of Proactive Motivation. Journal of Management, 36(4), 827-856. http://dx.doi.org.10.1023/A:1026792711025

Parker, S. K., Williams, H. M., \& Turner, N. (2006). Modeling the antecedents of proactive behavior at work. Journal of Applied Psychology, 91(3), 636-652. http://dx.doi.org.10.1037/0021-9010.91.3.636

Petrou, P., Demerouti, E., Peeters, M. C. W., Schaufeli, W. B., \& Hetland, D. J. (2012). Crafting a job on a daily basis: Contextual correlates and the link to work engagement. Journal of Organizational Behavior, 33(8), 1120-1141. http://dx.doi.org.10.1002/job.1783

Pierce, J. L., Gardner, D. G., Dunham, R. B., \& Cummings, L. L. (1993). The moderating effects of organization-based self-esteem on role condition-employee response relationships. Academy of Management Journal, 36, 271-288. http://dx.doi.org.10.1016/S0149-2063(99)00043-4

Podsakoff, P., \& MacKenzie, R. (1994). An examination of the psychometric properties and nomological validity of some revised and reduced substitutes for leadership scales. Journal of Applied Psychology, 79, 702-713. http://dx.doi.org.10.1037//0021-9010.79.5.702

Purcell, J. \& Hutchinson, S. (2007). Front-line managers as agents in the HRM-performance causal chain: theory, analysis and evidence. Human Resource Management Journal, 17(1), 3-20. http://dx.doi.org.10.1111/j.1748-8583.2007.00022.x

Rego, A., Pina, E., \& Cunha, M. (2009). Do the opportunities for learning and personal development lead to happiness? It depends on work-family conciliation. J Occup Health Psychol, 14(3), 334-348. http://dx.doi.org.10.1037/a0014248

Restubog, S., Bordia, P., \& Bordia, S. (2009). The interactive effects of procedural justice and equity sensitivity in predicting responses to psychological contract breach: an interactionist perspective. Journal of Business Psychology, 24(2), 65-178. http://dx.doi.org.10.1007/s10869-009-9097-1

Scholl, W. (2001). Effects of promotive and restrictive control on economic performance. In F. Butera \& G. Mugny (Eds.), Social influence in social reality. Promoting individual and social change (pp. 75-86). seattle: Hogrefe \& Huber.

Schriesheim, C. A., Neider, L. L., Scandura, T. A., \& Tepper, B. J. (1992). Development and preliminary 
validation of a new scale (LMX-6) to measure leader-member excbange in organizations. Educational and Psychological Measurement, 52, 135-147. http://dx.doi.org.10.1177/001316449205200119

Strauss, K., Griffin, M. A., \& Rafferty, A. E. (2009). Proactivity Directed Toward the Team and Organization: The Role of Leadership, Commitment and Role-breadth Self-efficacy. British Journal of Management, 20(3), 279-291. http://dx.doi.org.10.1111/j.1467-8551.2008.00590.x

Tims, M., \& Bakker, A. B. (2010). Job crafting: Towards a new model of individual job redesign. South African Journal of Industrial Psychology, 36(2), 1-9. http://dx.doi.org.10.4102/sajip.v36i2.841

Tims, M., Bakker, A. B., \& Derks, D. (2014). Daily job crafting and the self-efficacy - performance relationship. Journal of Managerial Psychology, 29(5), 490-507. http://dx.doi.org.10.1108/02683940710733115

Tims, M., Bakker, A. B., \& Derks, D. A. (2013). The Impact of Job Crafting on Job Demands, Job Resources, and Well-Being. Journal of Occupational Health Psychology, 18(2), 230-240. http://dx.doi.org.10.1037/a0032141

Van den Heuvel, M., Demerouti, E., \& Peeters, M. C. W. (2015). The job crafting intervention: Effects on job resources, self-efficacy, and affective well-being. Journal of Occupational and Organizational Psychology, 83(3), 511-532. http://dx.doi.org.10.1111/joop.12128

Vardaman, J. M., Gondo, M. B., \& Allen, D. G. (2012). Ethical climate and pro-social rule breaking in the workplace. Human Resource Management Review, 24(1), 108-118. http://dx.doi.org.10.1016/j.hrmr.2012.05.001

Walumbwa, F. O., Cropanzano, R., \& Goldman, B. M. (2011). How leader-member exchange influences effective work behaviors: social exchange and internal-external efficacy perspectives. Personnel Psychology, 64, 739-770. http://dx.doi.org.10.1111/j.1744-6570.2011.01224.x

Wayne, S. J., Shore, L. M., \& Liden, R. C. (1997). Perceived organizational support and leader member exchange: A social exchange perspective. Academy of Management Journal, 40(1), 82-111. http://dx.doi.org.10.2307/257021

Wrzesniewski, A., \& Dutton, J. E. (2001). Crafting a Job: Revisioning Employees as Active Crafters of Their Work. Academy of Management Review, 26(2), 179-201. http://dx.doi.org.10.5465/AMR.2001.4378011

\section{Copyrights}

Copyright for this article is retained by the author(s), with first publication rights granted to the journal.

This is an open-access article distributed under the terms and conditions of the Creative Commons Attribution license (http://creativecommons.org/licenses/by/4.0/). 